\title{
Pengaruh Konsentrasi Biostimulan Berbahan Aktif Bacillius subtilis dan Waktu Pemberian Terhadap Pertumbuhan dan Produksi Bawang Merah (Allium ascalonicum L.)
}

\author{
Effect of Active Biostimulant Concentration with an Active Agent of Bacillius subtilis and the \\ Application Time on Growth and Yield of Shallots (Allium ascalonicum L.)
}

\author{
Anggia Hattalaibessy ${ }^{1}$, Imelda J. Lawalata ${ }^{1}$, Henry Kesaulya ${ }^{2, *}$ \\ ${ }^{1}$ Program Studi Agroteknologi, Jurusan Budidaya Pertanian, Fakultas Pertanian, Universitas Pattimura, J1. Ir. M. \\ Putuhena Kampus Poka, Ambon 97233, Indonesia \\ ${ }^{2}$ Program Studi Pemuliaan Tanaman, Jurusan Budidaya Pertanian, Fakultas Pertanian, Universitas Pattimura, Jl. Ir. M. \\ Putuhena Kampus Poka, Ambon 97233, Indonesia \\ *E-mail Penulis Korespondensi: henry.unpat@gmail.com
}

\begin{abstract}
Shallot production is highly dependent on inorganic fertilizers because it provides high yields, but it turns out that it causes a lot of environmental problems. Organic and biological fertilizers containing bio stimulants have been developed as a more environmentally friendly alternative for vegetable production including shallot. This study is aimed at acquiring the right bio stimulant concentration and administration time to the growth and yield of shallot, as indicated by plant height, leaf size, biomass weight, bulb weight, total bulb weight percentage, leaf relative water content and the analysis of chlorophyll content. This research was arranged as a factorial experiment organized in a Randomized Block with two factors, i.e., bio stimulant concentration and administration time. Results of this studies showed that the combination of the bio stimulant concentration of $3.5 \mathrm{~mL} / \mathrm{L}$ with administration time of every 7 day was the best combination of treatments and could increase plant height, leaf number, tiller number, bulb weight, total bulb weight percentage, bulb number, canopy dry weight, relative water content and leaf chlorophyll.
\end{abstract}

Keywords: biostimulant, concentration, growth, shallot, yield

\section{ABSTRAK}

Produksi bawang merah sangat tergantung pada pupuk anorganik karena dapat memberikan hasil yang tinggi; tetapi ini ternyata berdampak menimbulkan masalah kerusakan lingkungan. Pupuk organik dan hayati yang mengandung biostimulan telah mulai dikembangkan sebagai alternatif yang lebih ramah lingkungan untuk produksi sayuran, termasuk bawang merah. Penelitian ini bertujuan untuk mendapatkan tingkat konsentrasi biostimulan dengan waktu pemberian yang tepat terhadap pertumbuhan dan produksi bawang merah, yang ditunjukkan oleh tinggi tanaman, jumlah daun, jumlah anakan, berat biomasa, berat umbi, presentase berat total umbi, jumlah umbi, berat kering tajuk, analisis kadar air relatif daun dan analisis kandungan klorofil daun. Penelitian ini dilakukan sebagai percobaan faktorial yang disusun dalam Rancangan Acak Kelompok dengan 2 faktor. Kedua faktor tersbut adalah tingkat konsentrasi biostimulan dan waktu pemberian. Hasil penelitian menunjukan bahwa konbinasi antara konsentrasi biostimulan 3,5 $\mathrm{mL} / \mathrm{L}$ dengan waktu pemberian 7 hari sekali merupakan kombinasi perlakuan terbaik dan dapat meningkatkan tinggi tanaman, jumlah daun, jumlah anakan, berat umbi, presentase berat total umbi, jumlah umbi, berat kering tajuk, kandungan air relatif dan klorofil daun.

Kata kunci: bawang merah, biostimulan, konsentrasi, pertumbuhan, produksi.

\section{PENDAHULUAN}

Bawang merah merupakan komoditas hortikultura yang banyak dikonsumsi dan berpotensi untuk dikembangkan secara luas di Indonesia (Suriani, 2011). Produksi bawang merah sangat tergantung pada pupuk anorganik karena memberikan hasil yang tinggi tetapi ternyata banyak menimbulkan masalah kerusakan lingkungan. Pupuk anorganik ini dapat mengganggu kehidupan dan keseimbangan tanah, meningkatkan dekomposisi bahan organik, yang kemudian menyebab- kan degradasi struktur tanah, kerentanan yang lebih tinggi terhadap kekeringan dan keefektifan yang lebih rendah dalam menghasilkan panen (Reijntjes et al., 2005). Fakta bahwa pupuk dan pestisida berperan penting saat ini dalam pertanian untuk meningkatkan produksi tanaman dan menjamin keberlanjutan produktivitas sepanjang musim. Beberapa inovasi teknologi untuk meningkatkan keberlanjutan 132 sistem produksi pertanian yang ramah lingkungan adalah penggunaan biostimulan tanaman alami yang dapat meningkatkan pertumbuhan, produktivitas tanaman, dan 
efisiensi penggunaan nutrisi, serta mampu meningkatkan toleransi terhadap berbagai stresor abiotik (Colla dan Rouphael, 2015).

Biostimulan adalah bahan organik yang mengandung zat-zat organik berkualitas tinggi, seperti asam amino, asam humit, vitamin, fitohormon, hara asensil dan terutama mengandung mikroflora menguntungkan (penambat $\mathrm{N}$, pelarut fosfat, penghasil hormon) untuk memacu pertumbuhan dan hasil tanaman (Saraswati dan Prihatini, 2004). Biostimulan bukan unsur hara atau pestisida namun berpengaruh positif terhadap pertumbuhan dan kesehatan tanaman serta ramah lingkungan (Calvo et al., 2014; du Jardin, 2015). Biositimulan merupakan formulasi senyawa bioaktif tanaman atau mikroorganisme yang dapat diaplikasikan pada tanaman dengan tujuan untuk meningkatkan efisiensi penyerapan nutrisi, toleransi cekaman, abiotik atau kualitas tanaman. Biostimulan tanaman merupakan zat atau mikroorganisme apa pun yang diaplikasikan pada tanaman dengan tujuan untuk meningkatkan efisiensi nutrisi, dan sifat kualitas tanaman, terlepas dari kandungan nutrisinya (du Jardin, 2015). Pengertian ini didukung oleh bukti ilmiah tentang mode aksi, sifat dan jenis efeknya pada tanaman pertanian dan hortikultura. Oleh Colla dan Rouphael (2015) dikemukakan enam kategori non-mikroba dan tiga mikroba, yaitu : 1) kitosan (Pichyangkura dan Chadchawan, 2015); 2) asam humat dan fulvat (Canellas et al., 2015); 3) protein hidrolisat (Colla et al., 2015); 4) fosfit (Gómez-Merino dan Trejo-Téllez, 2015); 5) ekstrak rumput laut (Battacharyya et al., 2015); 6) relatif (Savvas dan Ntatsi, 2015); 7) jamur mikoriza arbuskula (AMF) (Rouphael et al., 2015); 8) rhizobacteria pemacu pertumbuhan tanaman (PGPR; Ruzzi dan Aroca, 2015), dan 9) Trichoderma spp. (López-Bucio et al., 2015).

Kesaulya (2015) mengemukakan bahwa biostimulan memiliki multifungsi bagi tanaman, di lain pihak dapat juga sebagai penyedia unsur hara, meningkatkan ketersediaan hara, pengontrol organisme pengganggu tanaman, pengurai bahan organik dan pembentuk humus serta perombak persenyawaan kimia. Beberapa keberhasilan penggunaan biostimulan pada jagung, menunjukkan bahwa penggunaannya dapat meningkatkan berat trubus $37-42 \%$ dan berat akar 3445\% (Matysiak et al., 2011). Hasil yang sama juga terjadi pada tanaman kedelai, pemberian biostimulan secara signifikan mampu meningkatkan tinggi tanaman kedelai (Rathore et al., 2009), dan bobot segar tanaman sawi (Brassica juncea L.) (Saban et al, 2018). Pada tanaman lain belum banyak dilakukan penelitian, khususnya pada tanaman bawang merah. Tujuan penelitian ini adalah untuk mendapatkan taraf konsentrasi biostimulan dengan waktu pemberian yang tepat terhadap pertumbuhan dan produksi bawang merah.

\section{BAHAN DAN METODE}

Penelitian ini dilaksanakan di lahan sawah, Desa Gemba, Waimital, Kecamatan Kairatu, Kabupaten
Seram Bagian Barat. Varietas bawang merah yang digunakan adalah varietas Bauji yang diproduksi oleh Kelompok Tani Abdi Desa Wakal, Kec. Leihitu, Maluku Tengah. Biostimulan yang digunakan adalah biostimulan bersifat multi fungsi dan telah diujicobakan secara in vitro pada tanaman kentang dan diformulasikan pada Laboratorium Fisiologi Tanaman Fakultas Pertanian-Unpatti mengikuti prosedur yang dikemukakan oleh (Kesaulya, 2015 ; Kesaulya et al., 2015: Saban et al, 2018).

Penelitian ini merupakan percobaan faktorial yang disusun dalam Rancangan Acak Kelompok dengan 2 faktor, yaitu konsentrasi biostimulan (K) dan waktu pemberian biostimulan (W). Faktor pertama (K) terdiri dari 5 taraf, yaitu $\mathrm{K}_{0}$ (tanpa biostimulan dan NPK), $\mathrm{K}_{1}$ (NPK $20 \mathrm{~mL} / \mathrm{L}$ air), $\mathrm{K}_{2}$ (biostimulan 1,5 mL/L air), $\mathrm{K}_{3}$ (biostimulan $2,5 \mathrm{~mL} / \mathrm{L}$ air), $\mathrm{K}_{4}$ (biostimulan $3,5 \mathrm{~mL} / \mathrm{L}$ air).

Peubah pertumbuhan dan produksi tanaman yang diamati meliputi:

1. Tinggi tanaman $(\mathrm{cm})$ diukur mulai dari permukaan tanah sampai ujung tertinggi dengan meluruskan semua daun. Pengamatan dilakukan satu kali dalam seminggu.

2. Jumlah daun, ditentukan dengan cara menghitung semua daun yang terbentuk pada setiap satuan percobaan. Pengamatan dilakukan satu kali dalam seminggu.

3. Jumlah anakan, ditentukan dengan cara menghitung setiap anakan yang tumbuh dari pangkal akar tanaman pada setiap satuan percobaan. Pengamatan dilakukan satu kali dalam seminggu.

4. Berat biomasa, ditentukan dengan cara menimbang tanaman secara utuh pada setiap satuan percobaan, pada akhir percobaan.

5. Berat umbi, ditentukan dengan cara ditimbang pada saat pemanenan dengan menimbang umbi yang dihasilkan pada setiap satuan percobaan, pada akhir percobaan.

6. Presentase berat total umbi (g)

Presentase berat total umbi terhadap relelatif, NPK, biostimulan dan waktu pemberian dihitung dengan menggunkan rumus:

Presentase berat total umbi $(\%)=$

$$
\frac{Y_{\text {perlakuan }}-Y_{\text {kontrol }}}{Y_{\text {kontrol }}} \times 100
$$

7. Jumlah umbi, ditentukan dengan cara menghitung keseluruhan umbi yang dihasilkan pada setiap satuan percobaan, pada akhir percobaan.

8. Berat kering tajuk (g) ditentukan dengan cara mengeringkan tajuk dari setiap satuan percobaan dalam oven dengan suhu $80^{\circ} \mathrm{C}$ selama $3 \times 24$ jam. Pengamatan dilakukan pada akhir percobaan.

Peubah fisiologis yang diamati meliputi kadar air relatif daun dan analisis kandungan klorofil. Pengukuran kadar air relatif dilakukan berdasarkan metode Smart dan Bringham (1974). Untuk menghitung kandungan air relatif menggunakan rumus sebagai berikut: 


$$
K A R=\frac{\text { Bobot basah }(\mathrm{g})-\text { Bobot kering }(\mathrm{g})}{\text { Bobot jenuh }(\mathrm{g})-\text { Bobot kering }(\mathrm{g})} \times 100
$$
berikut:

Kandungan klorofil daun dihitung dengan rumus

Klorofil $(\mathrm{mg} / \mathrm{g})=(20.2 \mathrm{~A} 645+8.02 \mathrm{~A} 663) \times 25 / 1000 \times$ 0.5

Ekstrak klorofil diukur dengan spektrofotometer pada relatif gelombang 663 dan 645 nm (Arnon, 1949). Analisis terhadap masing-masing sampel diulang sebanyak tiga kali.

Data hasil pengamatan yang diperoleh dianalisis menggunakan program SAS (SAS Institute, North Carolina, Amerika Serikatdan Microsoft Excel 2007 (Microsoft Corporation, Redmond, Washington, Amerika Serikat). Apabila terdapat pengaruh perlakuan yang nyata pada analisis ragam, maka dilakukan uji lanjut untuk membedakan rata-rata antar konsentrasi perlakuan dengan menggunakan uji Beda Nyata Jujur ( $\alpha$ $=0,05)$

\section{HASIL DAN PEMBAHASAN}

Hasil analisis ragam menunjukan adanya pengaruh konsentrasi biostimulan dan waktu pemberian yang berbeda terhadap pertumbuhan dan produksi tanaman bawang merah (A. ascalonicum L.) seperti yang diperlihatkan pada Tabel 1.
Konsentrasi biostimulan memberikan pengaruh sangat nyata terhadap peubah tinggi tanaman, jumlah daun, jumlah anakan, baik pada 3 minggu setelah tanam (MST), 4 MST, 5 MSTdan 6 MST, serta berpengaruh sangat nyata terhadap berat umbi, jumlah umbi, berat kering tajuk, kandungan air relatif, dan kandungan klorofil daun. Tetapi biostimulan tidak berpengaruh nyata terhadap berat biomasa.

Waktu pemberian menunjukan pengaruh sangat nyata terhadap peubah tinggi tanaman pada 4 MST dan 5 MST, jumlah daun pada 5 MST dan 6 MST, jumlah anakan pada 4 MST, 5 MST dan 6 MST, kandungan air relatif dan kandungan klorofil daun. Hasil analisis ragam, waktu pemberian berpengaruh nyata terhadap peubah berat umbi, jumlah umbi dan berat kering tajuk, tetapi tidak berpengaruh nyata terhadap tinggi tanaman pada 3 MST dan 6 MST, jumlah daun pada 3 MST dan 4 MST, jumlah anakan pada 3 MST serta berat biomasa. Interaksi antara konsentrasi biostimulan dan waktu pemberian terhadap peubah tinggi tanaman pada 4 MST, 5 MST dan 6 MST, jumlah daun, jumlah anakan, berat kering tajuk, kandungan air relatif dan kandungan klorofil daun memberikan pengaruh sangat nyata. Pada peubah berat umbi dan jumlah umbi terdapat pengaruh nyata, tetapi tidak berpengaruh nyata terhadap biomasa tanaman dan tinggi tanaman dan tinggi tanaman pada 3 MST.

Tabel 1. Hasil analisis ragam pengaruh biostimulan terhadap pertumbuhan dan produksi bawang merah (A. ascalonicum L.).

\begin{tabular}{|c|c|c|c|c|}
\hline \multirow{2}{*}{\multicolumn{2}{|c|}{ Peubah }} & \multicolumn{3}{|c|}{ Perlakuan } \\
\hline & & $\mathrm{K}$ & $\mathrm{W}$ & $\mathrm{K} * \mathrm{~W}$ \\
\hline \multirow[t]{10}{*}{1.} & Tinggi Tanaman & & & \\
\hline & $-\quad 3 \mathrm{MST}$ & $* *$ & tn & tn \\
\hline & - $4 \mathrm{MST}$ & $* *$ & $* *$ & $* *$ \\
\hline & - $\quad 5 \mathrm{MST}$ & $* *$ & $* *$ & $* *$ \\
\hline & $-6 \mathrm{MST}$ & $* *$ & tn & $* *$ \\
\hline & Jumlah Daun & & & \\
\hline & $-\quad 3 \mathrm{MST}$ & $* *$ & $\operatorname{tn}$ & $* *$ \\
\hline & - $4 \mathrm{MST}$ & $* *$ & tn & $* *$ \\
\hline & $-\quad 5 \mathrm{MST}$ & $* *$ & $* *$ & $* *$ \\
\hline & $-\quad 6 \mathrm{MST}$ & $* *$ & $* *$ & $* *$ \\
\hline \multirow[t]{5}{*}{3.} & Jumlah Anakan & & & \\
\hline & $-3 \mathrm{MST}$ & $* *$ & tn & $* *$ \\
\hline & $-\quad 4 \mathrm{MST}$ & $* *$ & $* *$ & $* *$ \\
\hline & $-\quad 5 \mathrm{MST}$ & $* *$ & $* *$ & $* *$ \\
\hline & - $6 \mathrm{MST}$ & $* *$ & $* *$ & $* *$ \\
\hline 4. & Berat Biomasa & tn & tn & tn \\
\hline 5. & Berat Umbi & $* *$ & $* *$ & $* *$ \\
\hline 6. & Jumlah umbi & $* *$ & $*$ & $*$ \\
\hline 7. & Berat Kering Tajuk & $* *$ & $*$ & $* *$ \\
\hline 8. & Kandungan Air Relatif & $* *$ & $* *$ & $* *$ \\
\hline 9. & Kandungan Klorofil Daun & $* *$ & $* *$ & $* *$ \\
\hline
\end{tabular}

Keterangan: tn $=$ tidak nyata; $*$ nyata; $* *$ = sangat nyata 
Tabel 2. Rata-rata presentase berat total umbi terhadap kontrol dan NPK

\begin{tabular}{cccc}
\hline Perlakuan & Berat total & \multicolumn{2}{c}{ Presentase Berat total tanaman $(\%)$} \\
\hline K0W1 & 27,11 & - & - \\
K0W2 & 52,80 & 94,76 & - \\
K1W1 & 47,13 & 73,85 & 6,74 \\
K1W2 & 56,25 & 107,49 & 53,84 \\
K2W1 & 81,23 & 199,63 & 18,28 \\
K2W2 & 62,45 & 130,36 & 35,95 \\
K3W1 & 33,82 & 24,75 & 128,90 \\
K3W2 & 120,86 & 345,81 & 59,56 \\
K4W1 & 84,25 & 210,77 & 14,09 \\
K4W2 & 60,24 & 122,21 & \\
\hline
\end{tabular}

\section{Tinggi Tanaman}

Tinggi tanaman bawang merah diukur pada minggu ketiga setelah tanam, karena pada minggu pertama dan kedua tanaman bawang merah masih berada dalam tahap pertumbuhan awal serta masih beradaptasi dengan lingkungan tumbuhnya. Hasil uji beda nyata jujur interaksi antara konsentrasi biostimulan dan waktu pemberian terhadap peubah tinggi tanaman menunjukan pengaruh nyata, yaitu perlakuan konsentrasi $1,5 \mathrm{~mL} / \mathrm{L}$ dengan pemberian 7 hari sekali meningkatkan tinggi tanaman $33,66 \mathrm{~cm}$; konsentrasi 1,5 $\mathrm{mL} / \mathrm{L}$ dengan pemberian 14 hari sekali meningkatkan tinggi tanaman $33,63 \mathrm{~cm}$ dan konsentrasi $3,5 \mathrm{~mL} / \mathrm{L}$ dengan pemberian 7 hari sekali meningkatkan tinggi tanaman $33,33 \mathrm{~cm}$, bila dibandingkan dengan perlakuan lainnya serta dapat memacu tinggi tanaman.

\section{Jumlah Daun}

Hasil uji beda nyata jujur terhadap interaksi antara konsentrasi biostimulan dan waktu pemberian terhadap peubah jumlah daun menunjukan bahwa konsentrasi biostimulan $3,5 \mathrm{~mL} / \mathrm{L}$ dengan pemberian 7 hari sekali meningkatkan jumlah daun sebanyak 75,33 helai dan 41,00 helai untuk konsentrasi $1,5 \mathrm{~mL} / \mathrm{L}$ dengan pemberian 7 hari sekali. Kedua perlakuan ini memberikan pengaruh yang berbeda nyata dan dapat memacu jumlah daun tanaman.

\section{Jumlah Anakan}

Pembentukan anakan baru pada tanaman bawang merah dipengaruhi oleh berbagai factor dan salah satu faktor itu adalah sumber hara yang diserap oleh tanaman. Jumlah anakan mulai diamati pada 3 MST. Hasil uji beda nyata jujur terhadap interaksi antara konsentrasi biostimulan dan waktu pemberian untuk peubah jumlah anakan menunjukan bahwa pengaruh konsentrasi biostimulan $3,5 \mathrm{~mL} / \mathrm{L}$ dengan pemberian 7 hari sekali meningkatkan jumlah anakan sebanyak 10,66 anakan; konsentrasi $1,5 \mathrm{~mL} / \mathrm{L}$ dengan pemberian 7 hari sekali meningkatkan jumlah anakan sebanyak 5,33 anakan dan konsentrasi $2,5 \mathrm{~mL} / \mathrm{L}$ dengan pemberian 7 hari sekali meningkatkan jumlah anakan sebanyak 8,66 anakan, dan berbeda nyata dibandingkan dengan perlakuan lainnya.

\section{Berat Umbi Per Rumpun}

Berat umbi per rumpun dilakukan untuk mengetahui hasil umbi yang diproduksi selama pertumbuhan tanaman. Hasil uji beda nyata jujur terhadap interaksi antara konsentrasi biostimulan dan waktu pemberian untuk peubah berat umbi per rumpun menunjukan pengaruh konsentrasi biostimulan 2,5 $\mathrm{mL} / \mathrm{L}$ dengan pemberian 14 hari sekali meningkatkan berat umbi per rumpun sebanyak 120,86 g; konsentrasi biostimulan 3,5 mL/L dengan pemberian 7 hari sekali meningkatkan berat umbi per rumpun sebanyak 84,26 $\mathrm{g}$ dan $81,23 \mathrm{~g}$ pada konsentrasi bioatimulan $1,5 \mathrm{~mL} / \mathrm{L}$ dengan pemberian 7 hari sekali, serta berbeda nyata terhadap peubah berat umbi per rumpun dibandingkan dengan perlakuan lainnya.

Pengamatan berat total umbi (Tabel 2) memperlihatkan bahwa berat total umbi tanaman bawang merah dipengaruhi oleh kombinasi perlakuan biostimulan dan waktu pemberiannya. Konsentrasi biostimulan $2,5 \mathrm{~mL} / \mathrm{L}$ air dengan waktu pemberian 14 hari sekali dapat memacu berat total umbi tertinggi $345,81 \%$ lebih besar dibanding kontrol dengan waktu pemberian 7 hari sekali. Hal yang sama juga terjadi bila dibandingkan kontrol dengan waktu pemberian 14 hari sekali, kombinasi konsentrasi biostimulan $2,5 \mathrm{~mL} / \mathrm{L}$ air dengan waktu pemberian 14 hari sekali juga menunjukkan persentase yang lebih tinggi daripada perlakuan lainnya.

\section{Jumlah Umbi}

Jumlah umbi per rumpun, yaitu jumlah setiap umbi yang terdapat pada setiap rumpun dan setiap perlakuan, diamati sesudah panen dengan cara menghitung seluruh umbi yang terdapat pada rumpun bawang merah. Hasil uji beda nyata jujur terhadap interaksi antara konsentrasi biostimulan 2,5 mL/L dengan pemberian 7 hari sekali meningkatkan jumlah umbi sebanyak 13 umbi; konsentrasi biostimulan 1,5 $\mathrm{mL} / \mathrm{L}$ dengan pemberian 7 hari sekali meningkatkan jumlah umbi sebanyak 12,66 buah; konsentrasi 1,5 
$\mathrm{mL} / \mathrm{L}$ dengan pemberian 14 hari sekali meningkatkan jumlah umbi sebanyak 12 buah dan konsentrasi 3,5 $\mathrm{mL} / \mathrm{L}$ dengan pemberian 14 hari sekali meningkatkan jumlah umbi sebanyak 11,66, dan berbeda nyata dibandingkan dengan perlakuan lainnya.

\section{Berat Kering Tajuk}

Pengamatan berat kering tajuk bertujuan untuk mengukur banyaknya biomasa yang dihasilkanoleh tanaman. Hasil uji beda nyata jujur terhadap interaksi antara pengaruh konsentrasi biostimulan $3,5 \mathrm{~mL} / \mathrm{L}$ dengan pemberian 7 hari sekali meningkatkan berat kering tajuk sebesar 5,45 g; konsentrasi biostimulan 2,5 $\mathrm{mL} / \mathrm{L}$ dengan pemberian 14 hari sekali sebanyak $5,27 \mathrm{~g}$ dan 4,78 g pada konsentrasi 2,5 $\mathrm{mL} / \mathrm{L}$ dengan pemberian 7 hari sekali, serta berbeda nyata dibandingkan dengan perlakuan lainnya.

\section{Kandungan Air Relatif}

Kandungan air relatif (KAR) adalah rasio jumlah air dalam jaringan tanaman, dan ini merupakan pengukuran yang tepat untuk mengetahui status air tanaman di bawah kondisi cekaman karena ini menunjukan potensial air tanaman dan penyesuaian osmotik. Hasil uji beda nyata jujur interaksi antara konsentrasi biostimulan dan waktu pemberian terhadap peubah kandungan air relatif menunjukan pengaruh konsentrasi biostimulan $1,5 \mathrm{~mL} / \mathrm{L}$ dengan pemberian 7 hari sekali meningkatkan kandungan air relatif sebesar 47,74 g; konsentrasi biostimulan 3,5 mL/L dengan pemberian 14 hari sekali meningkatkan kandungan air relatif sebesar 42,93 g; konsentrasi biostimulan 2,5 $\mathrm{mL} / \mathrm{L}$ dengan pemberian 7 hari sekali meningkatkan KAR sebesar 42,85 g dan konsentrasi biostimulan 3,5 $\mathrm{mL} / \mathrm{L}$ dengan pemberian 7 hari sekali meningkatkan KAR sebesar 41,88 g, dan berbeda nyata dibandingkan dengan perlakuan lainnya.

\section{Kandungan Klorofil Daun}

Pengukuran klorofil daun bertujuan untuk mengetahui jumlah kandungan klorofil daun yang terdapat pada tanaman bawang merah. Kandungan klorofil daun tanaman bawang merah dilakukan pada laboratorium fisiologi tumbuhan dan laboratorium teknologi hasil pertanian, setelah tanaman selesai di panen. Hasil uji beda nyata jujur interaksi antara konsentrasi biostimulan dan waktu pemberian terhadap peubah kandungan klorofil daun menunjukan pengaruh konsentrasi biostimulan $1,5 \mathrm{~mL} / \mathrm{L}$ dengan pemberian 7 hari sekali meningkatkan kandungan klorofil daun sebanyak 2,20 mg/g, konsentrasi biostimulan $2,5 \mathrm{~mL} / \mathrm{L}$ dengan pemberian 14 hari sekali sebanyak $2,11 \mathrm{mg} / \mathrm{g}$ dan konsentrasi biostimulan 2,5 $\mathrm{mL} / \mathrm{L}$ dengan pemberian 7 hari sekali sebanyak $1,93 \mathrm{mg} / \mathrm{g}$ serta berbeda nyata dibandingkan dengan perlakuan lainnya dan dapat memacu kandungan klorofil daun tanaman.

\section{Rata-rata nilai produktivitas tanaman bawang merah}

Produktivitas tanaman bawang merah (Allium ascalonicum L.) diamati pada saat panen dengan menghitung jumlah umbi dan berat umbi. Perhitungan RAE (Relative Agronomic Effectiveness) dilakukan pada paramereter berat umbi untuk mengetahui nilai efektifitas biostimulan terhadap produktivitas saat panen. Nilai RAE dinyatakan efektif bila melebihi $100 \%$ dan tidak efektif bila kurang dari $100 \%$. Rata-rata nilai produktivitas tanaman bawang merah disajikan pada Tabel 3.

Tabel 3. Rata-rata produktifitas tanaman bawang merah (A. ascalonicum L.)

\begin{tabular}{cccc}
\hline \multirow{2}{*}{ Perlakuan } & Berat & \multicolumn{2}{c}{ RAE (\%) } \\
\cline { 3 - 4 } & Umbi & K0W1 & KOW2 \\
\hline \multirow{2}{*}{ KOW1 } & 27,11 & - & - \\
K0W2 & 52,80 & - & - \\
K1W1 & 47,13 & - & - \\
K1W2 & 56,25 & - & - \\
K2W1 & 81,23 & 270,33 & 824,06 \\
K2W2 & 62,45 & 176,52 & 279,71 \\
K3W1 & 33,82 & 33,52 & 550,14 \\
K3W2 & 12,86 & 486,28 & 1972,75 \\
K4W1 & 84,25 & 285,41 & 911,59 \\
K4W2 & 60,24 & 165,48 & 215,65 \\
\hline Keterangan: RAE $<100 \%$ : tidak efektif; RAE $>100 \%:$ efektif
\end{tabular}

Keterangan: RAE < $100 \%$ : tidak efektif; RAE > $100 \%$ : efektif

Pemberian biostimulan pada taraf dan waktu pemberian yang berbeda terhadap berat umbi tanaman bawang merah (Allium ascalonicum L.), menunjukkan bahwa perlakuan konsentrasi biostimulan $2,5 \mathrm{~mL} / \mathrm{L}$ air dengan pemberian 14 hari sekali lebih efektif memacu pembentukan umbi dibanding perlakuan lainnya, hal ini disebabkan karena perlakuan tersebut memiliki nila RAE 468,28 \% bila dibandingkan dengan kontrol, dimana nilai RAE mencapai 1972,75 \% dan dapat dikatakan lebih efektif dibanding perlakuan lainnya. Rata-rata nilai RAE terendah yaitu 33,52 \% dicapai pada konsentrasi biostimulan $2,5 \mathrm{~mL} / \mathrm{L}$ air dengan pemberian 7 hari sekali. Berdasarkan acuan penilaian nilai > $100 \%$ menunjukan bahwa biostimulan mampu meningkatkan produktivitas tanaman bawang merah saat panen.

Pertumbuhan tanaman merupakan hasil dari berbagai proses fisiologi, melibatkan faktor genotip yang berinteraksi dengan faktor lingkungan. Dengan adanya pertambahan tinggi tanaman maka tanaman akan mengalami pembelahan sel. Pertumbuhan tinggi tanaman dipengaruhi beberapa faktor, seperti lingkungan, fisiologi dan genetik dari tanaman. Proses tersebut antara lain meliputi pertumbuhan dan perkembangan tanaman. Ciri-ciri pertumbuhan pada tanaman yang tampak sebagai fenotip utamanya dipengaruhi oleh faktor genotip, sedangkan ciri-ciri lainnya ditentukan oleh pengaruh lingkungan sehingga 
pertumbuhan merupakan fungsi dari genotip dan lingkungan (Soedomo, 1992).

Pemberian biostimulan berbahan aktif Bacillus spp yang telah diformulasi dalam bentuk cair yang diaplikasikan dengan konsentrasi dan waktu pemberian berbeda dapat memacu pertumbuhan dan produksi tanaman bawang merah. Nutrisi yang didapat melalui pemberian biostimulan akan memacu berbagai mekanisme fisiologi pada tanaman. Aplikasi biostimulan juga dapat meningkatkan kualitas panen (Du Jardin, 2015).

Komponen-komponen tanaman pada tanaman bawang merah, seperti tinggi tanaman dan jumlah daun yang diamati merupakan peubah yang dapat diukur sebagai indikator pertumbuhan karena mengalami pertambahan ukuran dan jumlah pada setiap waktu pengamatan. Hasil analisis ragam pada peubah tinggi tanaman bawang merah menunjukan bahwa pemberian biostimulan, waktu pemberian dan interaksi keduanya berpengaruh sangat nyata pada 4 MST, 5 MST dan 6 MST terhadap tinggi tanaman dan mampu meningkatkan tinggi tanaman bawang merah, Tinggi tanaman bawang merah tertinggi yang dihasilkan yaitu $33,66 \mathrm{~cm}$. Laju pertumbuhan tanaman meningkat karena tanaman mulai memanfaatkan sumber nutrisi pada tanah akibat adanya interkasi antara tingkat konsentrasi dan waktu pemberian. Hal ini disebabkan karena adanya interaksi antara biostimulan dengan waktu pemberian sehingga memberikan efek terhadap pemacuan pertumbuhan tanaman dan adanya aktivitas fungsional dari bahan aktif dalam memfasilitasi penyediaan asupan nutrisi bagi tanaman (Kesaulya, 2015). Pertambahan tinggi tanaman terus terjadi dari 3 MST sampai 6 MST. Hal ini sejalan dengan Mulyani (2002) yang menyatakan bahwa semakin bertambahnya umur tanaman, diperlukan pula asupan unsur hara untuk memacu pertumbuhan.

Sama halnya dengan tinggi tanaman, perlakuan konsentrasi biostimulan juga berpengaruh nyata terhadap jumlah daun, jumlah anakan, berat umbi, jumlah umbi, berat kering daun, kandungan air relative dan klorofil daun.

Pertambahan jumlah daun dipengaruhi oleh adanya interaksi antara tingkat konsentrasi dan waktu pemberian biostimulan. Biostimulan memiliki multifungsi bagi tanaman dilain pihak juga sebagai penyedia unsur hara, meningkatkan ketersediaan hara, pengontrol organisme pengganggu tanaman, pengurai bahan organik dan pembentuk humus, serta perombak persenyawaan kimia (Kesaulya, 2015). Hasil analisis ragam menunjukan bahwa perlakuan tingkat konsentrasi, waktu pemberian dan interaksi keduanya berbeda nyata pada 3 MST, 4 MST, 5 MST dan 6 MST terhadap jumlah daun tanaman bawang merah, dengan jumlah daun terbanyak 75,33 helai pada 6 MST. Hal ini menunjukan bahwa konsentrasi biostimulan dan waktu pemberian mampu meningkatkan jumlah daun tanaman bawang merah. Hal ini diduga karena pada umur tersebut keberadaan unsur hara sudah cukup tersedia untuk diserap oleh akar tanaman, melalui pemberian biostimulan yang mampu memberikan nutrisi bagi tanaman dalam proses pertumbuhan vegetatif terutama pembentukkan daun.

Biostimulan memberikan ketersediaan nutrisi bagi tanaman bawang merah sehingga meningkatkan jumlah daun tanaman. Menurut (Sarief, 1986). Ketersediaan unsur hara yang dapat diserap tanaman merupakan salah satu faktor yang mempengaruhi pertumbuhan tanaman yang akan menambah pembesaran sel yang berpengaruh terhadap berat segar tanaman. Hal ini didukung oleh Du Jardin (2015) yang menyatakan bahwa aplikasi biostimulan bertujuan untuk meningkatkan efisiensi penyerapan nutrisi, toleransi cekaman abiotik dan meningkatkan kualitas panen, hal ini menunjukkan adanya aktifitas Bacillus spp. Sebagai bahan aktif dalam formulasi biostimulan.

Interaksi antara konsentrasi biostimulan dan waktu pemberian berbeda nyata pada setiap minggu pengamatan (3 MST, 4 MST, 5 MST dan 6 MST) terhadap jumlah anakan, dengan 10,66 anakan pada 6 MST. Pembentukan jumlah anakan pada tanaman bawang merah dipengaruhi oleh faktor lingkungan seperti panjang hari dan suhu. Abbas et al. (2014), mengemukakan bahwa bakteri yang diformulasi dalam biostimulan mampu menyediakan unsur hara makro, fiksasi $\mathrm{N}$, produksi hormon dan meningkatkan daya serap tanaman. Jumlah anakan tanaman bawang merah berkaitan dengan jumlah daun, jumlah daun yang optimum memungkinkan distribusi cahaya sebagai pembentukan fotosintat antar daun semakin merata, yang kemudian akan ditimbun pada batang dan akar yang akan berpengaruh terhadap jumlah anakan. Hasil fotosintesis yang tinggi akan memberikan hasil pertumbuhan tanaman dengan baik.

Umbi bawang merah merupakan bagian dari tanaman yang membesar sebagai tempat penyimpanan cadangan makanan. Berat umbi merupakan bobot basah umbi yang ditimbang langsung sesaat setelah tanaman dipanen. Bobot sangat ditentukan oleh kandungan kadar air yang terdapat pada sel-sel penyusun lapisan umbi. Pemberian biostimulan mampu meningkatkan kadar air tanaman agar unsur hara yang ada di dalam tanah dapat terserap dengan mudah oleh tanaman sehingga proses fotosintesis yang bertujuan untuk pembentukan umbi bawang merah dapat berlangsung dengan cepat. Hasil analisis ragam menunjukan bahwa perlakuan tingkat konsentrasi, waktu pemberian dan interaksi keduanya berbeda nyata. Interaksi antara perlakuan taraf konsentrasi biostimulan 2,5 $\mathrm{mL} / \mathrm{L}$ dengan waktu pemberian empat belas hari sekali pada K3W2 berbeda nyata, hal ini menunjukan bahwa konsentrasi biostimulan dan waktu pemberian mampu meningkatkan berat umbi per rumpun pada tanaman bawang merah, jumlah umbi per rumpun yang dihasilkan yaitu 120,86 g. Hal ini disebabkan karena bahan aktif biostimulan yang berasal dari risosfer mampu memfasilitasi ketersediaan unsur hara bagi tanaman sehingga dapat memacu pertumbuhan dan perkembangan tanaman (Kesaulya 2015; Kesaulya et al., 2015). 
Pemberian biostimulan mampu meningkatkan pembentukan klorofil daun yang berpengaruh terhadap pembentukam umbi tanaman bawang merah. Menurut Bambang Cahyono (2005) pembentukan umbi bawang merah berasal dari pembesaran lapisan-lapisan daun yang kemudian berkembang menjadi umbi bawang merah. Pembentukan klorofil yang sempurna dan banyak pada daun akan meningkatkan penyerapan energi cahaya matahari dalam proses fotosintesis. Semakin laju proses fotosintesis pada tanaman maka hasil fotosintat akan semakin banyak. Fotosintat yang dihasilkan berguna untuk pembentukan tubuh tanaman dan disimpan dalam umbi lapis bawang merah.

Hasil analisis ragam menunjukan bahwa perlakuan tingkat konsentrasi, waktu pemberian dan interaksi keduanya berbeda nyata. Interaksi antara perlakuan taraf konsentrasi biostimulan 2,5 $\mathrm{mL} / \mathrm{L}$ dengan waktu pemberian 7 hari sekali berbeda nyata, hal ini menunjukan bahwa konsentrasi biostimulan dan waktu pemberian mampu meningkatkan jumlah umbi per rumpun pada tanaman bawang merah. Jumlah umbi per rumpun yang dihasilkan yaitu 13 buah. Jumlah umbi yang tumbuh ditentukan dari jumlah anakan, jika jumlah anakan semakin banyak maka jumlah umbi yang dihasilkan juga semakin banyak, selain itu Luna (2010) menyatakan jumlah anakan yang tumbuh pada setiap rumpun tanaman akan mendukung jumlah umbi yang dihasilkan tiap rumpun tanaman tersebut. Semakin banyak anakan maka umbi yang muncul juga semakin banyak. Hal ini didukung oleh pendapat Craigie (2011) yang menyatakan bahwa salah satu efek positif dari pemberian biostimulan adalah meningkatkan pertumbuhan dan perkembangan akar tanaman.

Berat kering suatu tanaman merupakan suatu indikasi terjadinya penyerapan unsur hara yang dilakukan oleh tanaman dan laju penyerapan unsur hara tersebut ditentukan oleh akar tanaman. Pertambahan berat kering tajuk suatu tanaman terjadi karena pembentukan fotosintat menjadi biomasa yang tersimpan dalam tubuh tanaman. Produksi fotosintat akan meningkat apabila jumlah klorofil dalam daun bertambah banyak. Seperti yang telah dijelaskan sebelumnya, biostimulan mampu meningkatkan kandungan klorofil pada daun. Hasil analisis ragam menunjukan bahwa perlakuan tingkat konsentrasi, waktu pemberian dan interaksi keduanya berbeda nyata. Interaksi antara perlakuan taraf konsentrasi biostimulan 3,5 mL/L dengan waktu pemberian 7 hari sekali berbeda nyata, hal ini menunjukan bahwa konsentrasi biostimulan dan waktu pemberian mampu meningkatkan berat kering tajuk tanaman bawang merah, dengan berat kering tajuk yang dihasilkan yaitu 1,60 g. Pengamatan berat kering tajuk bertujuan untuk mengukur banyaknya biomasa yang dihasilkan oleh tanaman. Sebagian fotosintat yang diproduksi oleh klorofil ditransformasikan ke bagian tajuk tanaman yang kemudian diubah menjadi biomasa sebagai penyusun organ-organ tanaman.

Kandungan air relatif (KAR) adalah rasio jumlah air dalam jaringan tanaman pada saat pengambilan contoh dan pada turgiditas maksimum (Smart dan Bingham 1974). KAR merupakan pengukuran yang tepat untuk mengetahui status air tanaman di bawah kondisi stress karena KAR juga menunjukan potensial air tanaman dan penyesuaian osmotik (Suriya-Arunroj et al., 2004). Hasil analisis ragam menunjukan bahwa perlakuan tingkat konsentrasi, waktu pemberian dan interaksi keduanya berbeda nyata pada kandungan air relatif. Hal ini menunjukan bahwa konsentrasi biostimulan dan waktu pemberian mampu meningkatkan kandungan air relatif daun tanaman bawang merah sebanyak 47,74 g.

\section{KESIMPULAN}

Biostimulan berbahan aktif Bacillus spp pada konsentrasi $3.5 \mathrm{~mL} / \mathrm{L}$ dengan waktu pemberian 7 hari sekali berpengaruh terhadap peningkatan tinggi tanaman, jumlah daun, jumlah anakan, berat umbi, jumlah umbi, berat kering tajuk, kandungan air relatif dan klorofil daun.

\section{DAFTAR PUSTAKA}

Abbas, M.T., M.A. Hamza, H.H. Youssef, G.H. Youssef, M. Fayez, M. Monib, and N.A. Hegazi. 2014. Bio-preparates support the productivity of potato plants grown under desert farming conditions of North Sinai: Five years of field triarls. Journal of Advanced Research 5(1): 41-8. Doi: 10.1016/j.jare.

Battacharyya, D., M.Z. Babgohari, P. Rathor, and B. Prithivira. 2015. Seaweed extracts as biostimulants in horticulture. Sci. Hortic. 196: 39-48. DOI: 10.1016/j.scienta.2015.09.012

Cahyono, B. 2005. Bawang Daun, Teknik Budi Daya dan Analisis Usaha Tani. Penerbit Kanisius. Yogyakarta.

Calvo, P., L. Nelson, and J.W. Kloepper. 2014. Agricultural uses of plant biostimulants. Plant Soil 383: 3-41. DOI: 10.1007/s11104-014-21318

Canellas, L.P., F.L. Olivares, N.O. Aguiar, D.L Jones, A. Nebbioso, P. Mazzei, and A. Piccolo. 2015. Humic and fulvic acids as biostimulants in horticulture. Sci. Hortic. 196: 15-27. DOI: 10.1016/j.scienta.2015.09.013

Colla, G., and Y. Rouphael. 2015. Biostimulants in horticulture. Sci. Hortic. 196: 1-2. DOI: 10.1016/j.scienta.2015.10.044

Colla, G., S. Nardi, M. Cardarelli, A. Ertani, L. Lucini, R. Canaguier, and Y. Rouphael. 2015. Protein hydrolysates as biostimulants in horticulture. Sci. Hortic. 196:28-38. DOI: 10.1016/j.scienta. 2015.08.037

Craigie, J.S. 2011. Seaweed extract stimuli in plant science and agriculture. Journal of Applied Phycology 23: 371-393. 
du Jardin, P. 2015. Plant biostimulants: Definition, concept, main categories and regulation. Sci. Hortic. 196: 3-14.

Gómez-Merino, F.C. and L.I. Trejo-Téllez. 2015. Biostimulant activity of phosphate in horticulture. Sci. Hortic. 196: 82-90. DOI: 10. 1016/j.scienta.2015.09.035

Kesaulya, H. Baharuddin, B. Zakaria, S.A. Syaiful. 2015. Isolation and physiological characterization of PGPR from potato plant rhizosphere in medium land of Buru Island. Procedia Food Science 3: 190-199. DOI: 10. 1016/j.profoo.2015.01.021

Kesaulya. H. 2015. Bioprospek Rizobakteria Asal Kentang (Solanum tuberosum L.) Var. Hartapel Sebagai Pemacu Pertumbuhan Tanaman. Disertasi. Universitas Hasannudin, Makassar.

López-Bucio, J., R. Pelagio-Flores, and A. HerreraEstrella. 2015. Trichoderma as biostimulant: exploiting the multi level properties of a plant beneficial fungus. Sci. Hortic. 196: 109-123. DOI: $10.1016 /$ j.scienta.2015.08.043

Matysiak, K., S. Kaczmarek, and R. Krawczyk. 2011. Influence of seaweed extracts and mixture of humic acid fulvic acids on germination and growth of Zea mays L. Acta Sci. Pol. Agric. 10: 33-45.

Pichyangkura, R. and S. Chadchawan. 2015. Biostimulant activity of chitosan in horticulture. Sci. Hortic. 196: 49-65. DOI: 10.1016/j.scienta. 2015.09.031

Rathore, S.S., D.R. Chaudhary, G.N. Boricha, A. Ghosh, B.P. Bhatt, S.T. Zodape, and J.S. Patolia 2009. Effect of seaweed extract on the growth, yield and nutrient uptake of soybean (Glycine max) under rainfed conditions. South African Journal of Botany South African Journal of Botany 75: 351-355. DOI: 10.1016/j.sajb.2008. 10.009 .

Reijntjes, C., B. Haverkort, dan A. WatersBayer. 2005. Pertanian Masa Depan: Pengantar untuk
Pertanian Berkelanjutan dengan Input Luar Rendah. Penterjemah Sukoco, Y. Yayasan Kanisius, Yogyakarta.

Rouphael, Y., P. Franken, C. Schneider, D. Schwarz, M. Giovannetti, M. Agnolucci, S. De Pascale, P. Bonini, and G. Colla. 2015. Arbuscular mycorrhizal fungi act as biostimulants in horticultural crops. Sci. Hortic. 196: 91-108. DOI: $10.1016 /$ j.scienta.2015.09.002

Ruzzi, M. and R. Aroca. 2015. Plant growthpromoting rhizobacteria act as biostimulants in horticulture. Sci. Hortic. 196, 124-134. DOI: 10.1016/j.scienta.2015.08.042

Saban, R., H. Kesaulya, dan J.I. Nendissa. 2018. Pengaruh aplikasi biostimulan terhadap pertumbuhan dan produksi tanaman sawi (Brassica juncea L.). Jurnal Budidaya Pertanian 14: 41-46. DOI: 10.30598/jbdp.2018.14.1.41.

Saraswati, R. dan T. Prihatini. 2004. Teknologi pupuk mikroba untuk meningkatkan efisiensi dan keberlanjutan sistem produksi padi sawah. Dalam: A. Fahmuddin (Ed.) Tanah Sawah dan Teknoklogi Pengelolaannya. Pusat Penelitian dan Pengembangan Tanah dan Agroklimat. Bogor.

Sarief, S. 1986. Ilmu Tanah Pertanian. Bandung: Penerbit Pustaka Buana.

Savvas, D. and G. Ntatsi. 2015. Biostimulant activity of silicon in horticulture. Sci. Hortic. 196:66-81. DOI: $10.1016 /$ j.scienta.2015.09.010

Smart, R.E. and G.E. Bingham. 1974. Rapid estimates of relative water content. Plant Physiol. 53: 258260.

Soedomo, P. 1992. Uji adaptasi dan daya hasil kultivar bawang merah (Allium ascalonicum L.) di daerah Pasar Minggu. Buletin Penelitian Hortikultura 23(4): 128-135.

Suriya-arunroj, D., N. Supapoj, T. Toojindab, and A. Vanavichitb. 2004. Relative leaf water content as an efficient method for evaluating rice cultivars for tolerance to salt stress. Science Asia 30: 411415. 